\title{
Obituary
}

\section{Dr Nathaniel Minton MA, DPM, FRCPsych}

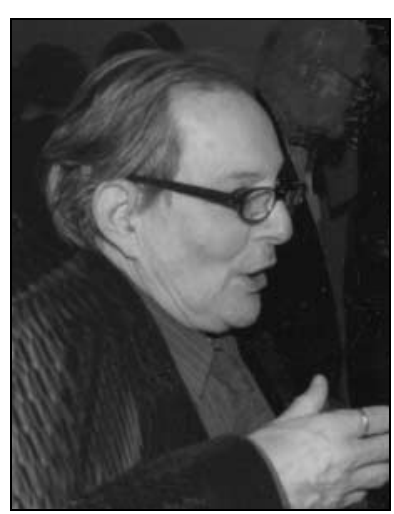

Formerly consultant psychiatrist, St Peter's Hospital, Chertsey, The Priory, and Capio Nightingale Hospital, London

Dr Nathaniel Minton, who was born on 28 May 1935, had a unique training in psychiatry for a British graduate, because he spent 3 years (1965-1968) training in psychoanalysis and depth psychotherapy at the C. G. Jung Institute in Zurich, trained individually by Jolande Jacobi, Jung's senior deputy. When later, in 1979, he became a consultant psychiatrist at St Peter's Hospital, Chertsey, he was also recognised as being a psychotherapist at the Royal Holloway University of London.

Nathaniel was educated at St Paul's School, London, and Trinity College, Cambridge, and obtained an MA (Cantab) in 1956 in Natural Sciences. From 1956 to 1959, he studied medicine at the West London (Charing Cross) Medical School, and after graduation, he spent 1 year in Teleshamir Hospital in Tel Aviv.

On returning to London in 1968, he worked for 1 year as a psychiatric registrar at the Princess Alexandra Hospital, Harlow, Essex, and then spent 10 years as a senior registrar, first at Newcastle under Sir Martin Roth for 3 years, and then for 1 year at Napsbury Hospital, followed by 4 years at Long Grove Hospital, Epsom.

In 1979, he became a consultant psychiatrist with a specialist interest in psychotherapy at St Peter's Hospital, Chertsey, and the Royal Holloway University. He was also working under his contract at the Holloway Sanatorium and the Abraham Cowley Unit, St Peter's Hospital. He became a member of the board of examiners of the Royal College of Psychiatrists, of which he had become a Fellow. He also became a tutor for the Royal College of Psychiatrists and the British Postgraduate Medical Federation. He worked for 20 years at the Priory Hospital and from 2000 at the private Capio Nightingale Hospital, London.

From 2000 to 2007, he was a member of the Mental Health Act Review Tribunal and a member of the Mental Health Act Commission. He was an author of a section in Contemporary Themes in Psychiatry (Gaskell, 1989) and produced several University of London films on psychiatry and psychotherapy, including 'Current Perspectives on Sleep' (1984), 'Art Therapy and Psychiatry' (1988), 'An Interview with Professor C.A. Meier, director of the Jung Institute', 'An Interview with Professor Sir Martin Roth' and 'Psychiatry in the Millennium' (2000). From 2002 to 2008, he was a major organiser of a series of influential international conferences on conflict resolution, focusing on global conflicts. He has also written a memoir of his friend the poet Ted Hughes, which is awaiting publication.

In 1987, he lectured in Jerusalem on 'The Artistry of the Mentally III Past and Present'. He also lectured on conflict resolution at the World Association for Dynamic Psychiatry in Munich (2001) and St Petersburg (2007), at the World Association for Social Psychiatry in Agra, India, and at the World Psychiatric Association Congress in Istanbul (2006).

Nathaniel Minton was a devoted husband to his wife Helen, proud father to his daughter Anna and son Aris, happy grandfather to his grandson Thomas, an amiable host and always an interesting person. In recent years he had been very ill with myelodysplasia but fought his condition with bravery. He died on 25 November 2012.

He was an optimist and always believed there was hope of settlements between warring nations such as Israel and its neighbours, and was the leading light in organising conferences on conflict resolution; a subject now mandatory for the Royal College of Psychiatrists.

Dr Lewis Clein

doi: 10.1192/pb.bp.113.043661

\section{Correction}

Mental Health Act 1983: use of urgent treatment in clinical practice. The Psychiatrist 2013; 37: 156-159. The Method (p. 157) should read: 'The study was conducted retrospectively covering a 1-year period from January 2009 to December 2009. A list of detained patients, on whom Sections 62 and $64 \mathrm{~B}$ were applied during the study period, was obtained electronically from the IT department. A complete list of patients on whom T2 or T3 forms were filled and patients who were commenced on a CTO was also obtained electronically. Also, Section 64 and CTO11 forms were obtained from the Mental Health Act office of the trust. Respective case notes were then located and more detailed information was obtained on the circumstances of use of Section 62 and 64B/G.'

doi: 10.1192/pb.bp.113.044008 